\title{
Taxes and Charges in Road Freight Transport - a Comparative Study of the Level of Taxes and Charges in the Slovak Republic and the Selected EU Countries
}

\author{
Vladimír Konečný \\ University of Žilina \\ Faculty of Operation and Economics of \\ Transport and Communications \\ Department of Road and Urban Transport \\ Slovak Republic \\ e-mail: vladimir.konecny@fpedas.uniza.sk
}

\author{
Štefánia Semanová \\ University of Žilina \\ Faculty of Operation and Economics of \\ Transport and Communications \\ Department of Road and Urban Transport \\ Slovak Republic \\ e-mail: stefania.semanova@fpedas.uniza.sk \\ Jozef Gnap \\ University of Žilina \\ Faculty of Operation and Economics of Trans- \\ port and Communications \\ Department of Road and Urban Transport \\ Slovak Republic \\ e-mail: jozef.gnap@fpedas.uniza.sk
}

\author{
Ondrej Stopka \\ Institute of Technology and Business in \\ České Budějovice \\ Faculty of Technology, \\ Department of Transport and Logistics \\ Czech Republic \\ e-mail: stopka@mail.vstecb.cz
}

DOI $10.17818 / \mathrm{NM} / 2018 / 4 \mathrm{SI} .8$

UDK 656.11 (437.6)

Original scientific paper

Paper accepted: 28. 8. 2018.

\section{Summary}

The paper deals with the issue of taxes and charges in road freight transport in the Slovak Republic and the selected European countries. The aim is to compare and evaluate the position of the Slovak carriers towards foreign ones when doing business in the common European market. The selected kinds of taxes and charges (or costs items) relate to different production factors of road transport undertakings (vehicles, drivers, road infrastructure). Also, the legislation on taxes and charges differs among individual countries and differences can be observed in the principles of taxation. The objective is to make a comprehensive objectified comparison when taking into account several selected taxes, charges and costs in road transport.

\section{KEY WORDS}

road freight transport

taxes

charges

costs

European market

\section{INTRODUCTION}

The proportion of taxes and charges of the total costs of carriers is different. Their proportionality also varies among countries. Individual kinds of taxes and charges are related to different production factors of road transport undertakings. Some of them relate to the transport route, the used road infrastructure, and the others are associated with the vehicle operation, vehicle crew i.e. the subject to which the taxes and charges are applied is different. The values of these taxes and charges in individual countries change over time, and these changes are not time and territorial coordinated. They affect the cost level as well as pricing of carriers and this has an impact on the competitiveness, business sustainability and the profitability of transport companies. Consequently, this has an impact on the whole market in the freight transport sector. Therefore, it is necessary to look for possibilities for the complex and objectified assessment of the tax burden and charges of carriers.

Taxes and charges in road freight transport may be divided into two groups. The first group is related to the place of carrier establishment in a given country, e.g. motor vehicle tax, corporate income tax, property tax, charges associated with the vehicle registration, vehicle technical and emission inspection, etc. Disproportions among countries arise mainly in this group. The second group includes the charges related to the transport route, e.g. toll, parking fees, charges for ferries, etc. These charges are borne by carriers from different countries in the same amount.
This paper was processed also based on the results and findings obtained from the expert studies and projects addressed by the authors in the area of motor vehicle taxation [1], [2], and other taxes, charges and costs in road transport [3].

\section{DATA AND MATERIAL}

The scientific papers and research are more focused on individual taxes and charges, e.g. in [4]. or the tax burden and charges in road transport at the level of individual countries (e.g. in [5]), but not on the international comparison with the use of a set of related taxes and charges. A comparison of transport policies in road transport and road infrastructure charging in Germany and Sweden was addressed in [6]. The impacts of the introduction of infrastructure charging in the UK and Ireland were examined in [7].

Road freight transport must be seen not only as a competitive transport mode for water transport [8] but also as an essential part of the logistics chain and multimodal transport with the aim to ensure carriage of raw materials and distribution of goods within the inland of Europe [9], [10].

The tax burden assessment based on one type of the tax or charge by using one-criterion methods is insufficient and distorted. Therefore, the objective of this paper is to make a more comprehensive and more objective assessment of the position of Slovak carriers in the European market with regard to the tax burden and charges in road freight transport with the 
use of scientific methods.

A limiting factor is the availability of relevant data on taxes and charges.

The research of the paper is conducted for the following set of indicators - taxes and charges which relate to transport service provision for commercial purposes in road freight transport:

- $U_{1}$ - corporate income tax rate [\%],

- $\quad U_{2}-$ minimum wage for the degree of labour difficulty corresponding to drivers in road freight transport [ $€ /$ month],

- $\quad U_{3}$ - levies paid by employers (mandatory social and health insurance contributions) [\%],

- $U_{4}$ - motor vehicle tax [€/year],

- $\quad U_{5}$ - excise duty on mineral oil [€/1 000 litres],

- $\mathrm{U}_{6}$ - price of diesel without VAT [€/litre],

- $\quad U_{7}$ - charges for road infrastructure [€/km].

The sources for values of the indicators were Taxes in Europe Database (TEDB) of the Europe Commission, national legislation in the area of taxes and charges, statistical authorities of individual countries as well as source [10]. The data from various sources were analysed, verified and consolidated for 2016.

The values of $U_{4}$ and $U_{7}$ indicators are dependent on the vehicle category and its technical parameters. The procedure of determining motor vehicle tax as well as toll rates widely differs between countries, e.g. [11]. In terms of motor vehicle taxation, the tax rate is determined separately for a semi-trailer and tractor unit (e.g. in SK, CZ, PL, HU, DE); however, different approaches are applied to determine the tax rate level [12], [13]. Therefore, an articulated vehicle of the total weight of 40 tonnes, typically used in international road freight transport, is taking into account for the purpose of determining and comparing the value of taxes and toll. The technical parameters of the articulated vehicle under consideration are:

- tractor unit:

- the maximum permissible total weight: $18000 \mathrm{~kg}$,

- 2 axles; the maximum permissible axle weight: $7100 \mathrm{~kg}$, $11500 \mathrm{~kg}$ (i.e. in total $18600 \mathrm{~kg}$ ),
- vehicle kerb weight: 6900 kg,

- air suspension.

- semi-trailer:

- the maximum permissible total weight: $34000 \mathrm{~kg}$,

- 3 axles; the maximum permissible axle weight: $8000 \mathrm{~kg}$, 8000 kg, 8000 kg (i.e. in total 24000 kg),

- vehicle kerb weight: $6250 \mathrm{~kg}$,

- maximum payload: $27750 \mathrm{~kg}$,

- air suspension.

Considering the market competition of international road transport and the common or similar economic and social development, a comparison of the selected indicators is carried out for the countries of Central and Eastern Europe as well as developed Western European countries. Based on the availability of indicator values, the comparison includes 12 countries.

The values of examined indicators for the compared countries are given in Table 1. The table provides the determination of average values and variability of indicators. The data are then used for calculating the standardized values of the indicators.

\section{METHODS AND RESULTS}

The problem of the set of indicators expressed in absolute terms lies in the variability of indicator values as well as differences of the unit expression of individual indicators. Assessment of the tax burden and charges within the selected countries is carried out by the used of multi-criteria methods, i.e. by using the standardized variable method and the method of distance to the fictitious object. These methods were used by, for example [14], [15] in assessing regional disproportions. However, these methods have not been used to assess the differences in taxes and charges in road transport among countries, yet.

\subsection{Standardized variable method and its application}

The standardized variable method is based on the so-called standardizing - a statistical procedure in which the original

Table 1 Indicator values

\begin{tabular}{|c|c|c|c|c|c|c|c|}
\hline \multirow{3}{*}{ COUNTRY } & \multicolumn{7}{|c|}{ INDICATOR $\left(x_{i j}\right)$} \\
\hline & $\mathrm{U}_{1}$ & $\mathrm{U}_{2}$ & $\mathrm{U}_{3}$ & $\mathrm{U}_{4}$ & $U_{5}$ & $\mathrm{U}_{6}$ & $\mathrm{U}_{7}$ \\
\hline & $\left(x_{i 1}\right)$ & $\left(x_{i 2}\right)$ & $\left(x_{i 3}\right)$ & $\left(x_{i 4}\right)$ & $\left(x_{i 5}\right)$ & $\left(x_{i 6}\right)$ & $\left(x_{i 7}\right)$ \\
\hline AT & 25 & 1599 & 21.5 & 1142 & 425 & 0.857 & 0.4060 \\
\hline BG & 10 & 235 & 18.74 & 942 & 330 & 0.865 & 0.0085 \\
\hline $\mathrm{CZ}$ & 19 & 496 & 34 & 1110 & 398 & 0.869 & 0.1670 \\
\hline $\mathrm{DE}$ & 31.5 & 1532 & 20.325 & 929 & 486 & 0.974 & 0.1560 \\
\hline $\mathrm{EE}$ & 20 & 470 & 36.3 & 512 & 393 & 0.857 & 0 \\
\hline FR & 28 & 1676 & 50 & 1032 & 468 & 1.029 & $-*$ \\
\hline $\mathrm{HU}$ & 9 & 412 & 22 & 1270 & 366 & 0.917 & 0.2900 \\
\hline $\mathrm{LT}$ & 15 & 380 & 31.79 & 570 & 330 & 0.88 & 0.0048 \\
\hline LV & 15 & 380 & 23.59 & 230 & 333 & 0.871 & 0.0045 \\
\hline PL & 19 & 454 & 20.43 & 728 & 349 & 0.799 & 0.0610 \\
\hline RO & 16 & 308 & 23.1 & 484 & 430 & 0.892 & 0.0077 \\
\hline SK & 21 & 522 & 35.2 & 2462 & 386 & 0.854 & 0.1810 \\
\hline Average value () & 19.042 & 705.333 & 28.081 & 950.917 & 391.167 & 0.889 & 0.117 \\
\hline Standard deviation & 6.456 & 524.167 & 9.031 & 546.146 & 50.747 & 0.058 & 0.131 \\
\hline
\end{tabular}

Source: authors 
values of individual indicators are transformed into a standard and theoretical form which is quantified by dimensionless numbers. By this procedure, it is possible to eliminate the variability within the same indicators among individual compared countries. Thus, the original indicator values of the tax burden and charges are replaced by the values of standardized variables.

The arithmetic average and the standard deviation are calculated for individual indicators. Subsequently, the values of standardized variables are calculated by using the following formula (1):

$$
u_{i j}=\frac{x_{i j}-\bar{x}_{\mathbf{j}}}{s_{j}}
$$

Where:

- $\quad u_{i j}$ - the standardized variable of the $i$-th country, of the $j$-th indicator, $i=1,2, \ldots n ; j=1,2, \ldots . m$,

- $\quad x_{i j}$ - the value of the $i$-th country, of the $j$-th indicator, $i=$ $1,2, \ldots n ; j=1,2, \ldots m$,

- $\quad \bar{x}_{\mathrm{j}}$ - the arithmetic average of the $j$-th indicator, $j=1,2, \ldots m$,

- $\quad s_{j}$ - the standard deviation of the $j$-th indicator, $j=1,2, \ldots m$.

Then, the sum of standardized variable values is calculated for individual countries according to the following formula (2):

$$
Z i=\sum_{j=1}^{m} u_{i j}
$$

Where:

- $\quad Z_{i}$ - the sum of the standardized $j$-th variables for the $i$-th country,

- $\quad m$ - the number of indicators.

Subsequently, the average of the indicator standardized value for a given country is determined based on the following formula (3):

$$
\bar{x}_{N H_{i}}=\frac{Z i}{m}
$$

Where:

- $\bar{x}_{N H_{i}}$ - the average of the standardized values of indicators for the $i$-th country, $i=1,2, \ldots . n$,

The resultant ranking of individual countries is arranged in the order from the lowest value (ranking 1 ) to the highest value (ranking $n$ ).

The calculated standardized variable values of the indicators of the tax burden and charges are shown in Table 2. Based on the average of standardized indicators, the order of the examined countries was determined.

According to this method, the country with the lowest tax burden and charges (or costs) is Bulgaria, followed by Latvia, Poland, Lithuania and Romania. On the contrary, Austria, Germany and France are countries with the highest tax burden. The Slovak Republic is ranked right behind these Western European countries i.e. on the $9^{\text {th }}$ place. When comparing the countries of Central and Eastern Europe, the Slovak Republic reaches the highest tax burden in relation to the used set of indicators.

\subsection{Method of distance to the fictitious object and its application}

The method of distance to the fictitious object uses the standardized variables. The fictitious object represents an ideal model country which reaches the best values of the individual indicators in the given area (the lowest tax rates and charges). Thus, the best value was determined for the given indicator, i.e. the minimum standardized value from calculated standardized values (from Table 2). This value was then used as the ideal model for the given indicator.

The standardized variables are calculated for individual indicators in similar way as in the case of the standardized variable method. However, the ideal indicator value (minimum value) is used instead of the average value of the indicator when calculating the standardized variable. The calculation is realised according to the following formula (4):

$$
u_{j \min }=\frac{x_{j \min }-x_{i j}}{s_{j}}
$$

Where:

\begin{tabular}{|c|c|c|c|c|c|c|c|c|c|c|}
\hline \multirow{3}{*}{ COUNTRY } & \multicolumn{7}{|c|}{ INDICATOR $\left(u_{i j}\right)$} & \multirow[b]{2}{*}{ SUM } & & \multirow{3}{*}{$\begin{array}{l}\text { ORDER OF } \\
\text { COUNTRIES }\end{array}$} \\
\hline & $\mathrm{U}_{1}$ & $\mathrm{U}_{2}$ & $\mathrm{U}_{3}$ & $\mathrm{U}_{4}$ & $\mathrm{U}_{5}$ & $\mathrm{U}_{6}$ & $\mathrm{U}_{7}$ & & $\begin{array}{l}\text { OF THE } \\
\text { STANDAR. } \\
\text { VALUES }\end{array}$ & \\
\hline & $\left(u_{i i}\right)$ & $\left(u_{i 2}\right)$ & $\left(u_{i 3}\right)$ & $\left(u_{i 4}\right)$ & $\left(u_{i j}\right)$ & $\left(u_{i 6}\right)$ & $\left(u_{i}\right)$ & $Z_{i}$ & & \\
\hline AT & 0.923 & 1.705 & -0.729 & 0.350 & 0.667 & -0.552 & 2.206 & 4.570 & 0.653 & 10 \\
\hline BG & -1.401 & -0.897 & -1.034 & -0.016 & -1.205 & -0.414 & -0.828 & -5.796 & -0.828 & 1 \\
\hline$C Z$ & -0.007 & -0.399 & 0.655 & 0.291 & 0.135 & -0.345 & 0.382 & 0.712 & 0.102 & 8 \\
\hline $\mathrm{DE}$ & 1.930 & 1.577 & -0.859 & -0.040 & 1.869 & 1.466 & 0.298 & 6.240 & 0.891 & 11 \\
\hline $\mathrm{EE}$ & 0.148 & -0.449 & 0.910 & -0.804 & 0.036 & -0.552 & -0.893 & -1.603 & -0.229 & 6 \\
\hline$F R$ & 1.388 & 1.852 & 2.427 & 0.148 & 1.514 & 2.414 & $-*$ & 9.743 & 1.624 & 12 \\
\hline $\mathrm{HU}$ & -1.555 & -0.560 & -0.673 & 0.584 & -0.496 & 0.483 & 1.321 & -0.897 & -0.128 & 7 \\
\hline LT & -0.626 & -0.621 & 0.411 & -0.697 & -1.205 & -0.155 & -0.856 & -3.751 & -0.536 & 4 \\
\hline LV & -0.626 & -0.621 & -0.497 & -1.320 & -1.146 & -0.310 & -0.859 & -5.379 & -0.768 & 2 \\
\hline $\mathrm{PL}$ & -0.007 & -0.479 & -0.847 & -0.408 & -0.831 & -1.552 & -0.427 & -4.551 & -0.650 & 3 \\
\hline RO & -0.471 & -0.758 & -0.552 & -0.855 & 0.765 & 0.052 & -0.834 & -2.653 & -0.379 & 5 \\
\hline SK & 0.303 & -0.350 & 0.788 & 2.767 & -0.102 & -0.603 & 0.489 & 3.292 & 0.470 & 9 \\
\hline
\end{tabular}

- $u_{\mathrm{j} \text { min }}$ - the standardized variable of the $i$-th country, of the $j$-th indicator, $i=1,2, \ldots n ; j=1,2, \ldots m$,

Table 2 Assessment of the tax burden of carriers by using the standardized variable method

Source: authors 
- $\quad \mathrm{x}_{\mathrm{jmin}}$ - the minimum (ideal) value of the $i$-th country, of the $j$-th indicator, $i=1,2, \ldots . . n, j=1,2, \ldots m$.

The standardized values of indicators are used to calculate the integral indicator by using the formula (5). This represents the Euclidean distances of the individual countries from the ideal values of the fictitious object.

For the individual countries, the Euclidean distances from the fictitious object were thus calculated by using the integral indicator expressed by the formula (5). The values of standardized indicators obtained by using the formula (1) and provided in Table 2 were also used in the calculation.

$$
d_{i, 0}=\sqrt{\frac{1}{m} \cdot \sum_{j^{\prime}=1}^{m}\left(u_{i, j}-u_{j \min }\right)^{2}}
$$

Where:

- $\mathrm{d}_{\mathrm{i}, 0}$ - the Euclidean distance for the $i$-th country, $i=1,2 \ldots n$,

- $\quad m$ - the number of indicators.

The resultant order of countries was determined based on the distance from the fictitious object (the value of $d_{j, 0}$ ). The individual countries were thus arranged in the order from the lowest value of $d_{j, 0}$ (ranking 1 ) to the highest value of $d_{j, 0}$ (ranking $n$ ). The best country represents a country of which the distance from the fictitious (ideal) country is the lowest, i.e. the integral indicator value is minimal. The calculated values are shown in Table 3.

The method of distance from the fictitious object is considered to be the most accurate method among the selected methods. The reason for this statement is that it quantifies the total distance of the individual countries from a certain point. It also eliminates the impact of extreme values in comparison with the standardized variables method.

The methods used in the paper differently express the relationship among the indicators. They demonstrate slight differences in the resultant order of countries regarding the tax burden and charges. When ranking the selected 12 countries by using two mentioned methods, the difference may be observed in four cases (Table 2 and 3).

Therefore, a conformity test of the order achieved by both methods was performed. Spearman's rank correlation coefficient was used by using the following formula (6):

$$
R=1-\frac{6 \cdot \sum\left(i_{x}-i_{y}\right)^{2}}{n \cdot\left(n^{2}-1\right)}
$$

Where:

- $\quad i_{x}$ - the order obtained by using the standardized variable method,

- $\quad i_{y}$ - the order obtained by using the method of distance from the fictitious object,

- $\quad n$ - number of compared countries.

The calculated Spearman's rank correlation coefficient represents the value of 0.986 . It can be stated that the standardized variable method and the method of distance from the fictitious object, which were used to determine the order of the selected countries, provide the results with close conformity of ranking. Therefore, both methods may be used for assessment of the selected countries regarding the tax burden and charges of carriers.

\section{CONCLUSION}

The position of the selected European countries in the area of the tax burden and charges in road freight transport is significantly different. Based on the complex comparison, it can be concluded that the level of tax burden and charges of carriers in the Slovak Republic is the highest among the countries of Central and Eastern Europe. The methods used in the paper objectively determine the order of countries according to the tax burden in road freight transport. The reason for approach based on the order of countries is the fact that the changes in taxes and charges are unsystematic and uncoordinated among the countries not only in terms of their level but also in the change intensity in terms of time.

The carriers are forced to include the increased taxes and charges into prices for services provided, e. g. [16]. This may worsen the competitiveness in the European market of road freight transport for the carriers from the countries with the highest tax burden and charges. The risk represents especially the different level of tax rates and charges relating to the place of carrier establishment.

Table 3 Method of distance to the fictitious object

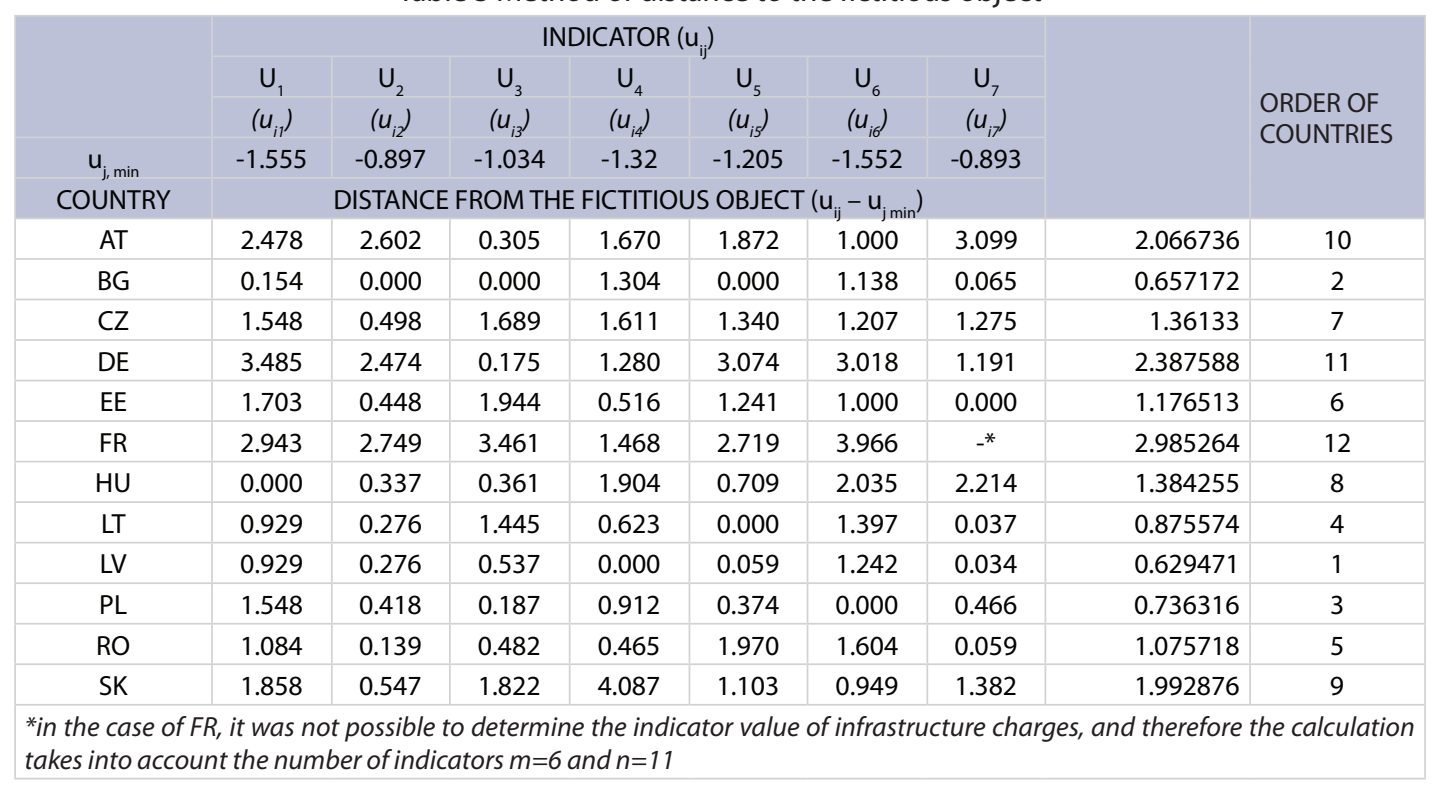


The tax burden of transport and logistics services generate sources which should be reallocated to transport for the purposes of improving transport infrastructure, supporting business development and employment in the sector [17], [18].

The aim for future research is to extend the number of assessed countries and the set of indicators as well as to examine the structure of ways and differences of taxation in European countries e.g. in regard to corporate income tax, the way of calculating the tax base including deductible items relating to vehicles in the form of tax depreciation, lease payments, etc.

Regarding $\mathrm{U}_{4}$ indicator - motor vehicle tax, the data analysis and research showed disproportions in tax rates as well as in ways of taxation. Moreover, there are countries (Latvia, Romania, Estonia) which still do not apply the statutory minimum rates for motor vehicle tax in accordance with Directives [19], [20]. Tax rates under the set minimum in given countries are even mentioned in the European Union document [21].

\section{Acknowledgement}

This paper has been developed under support of project: MŠVVŠ SR VEGA No. 1/0566/18 KONEČNÝ, V.: Research on the impact of supply and quality of transport services on the competitiveness and sustainability of demand for public transport

\section{REFERENCES}

[1] Gnap. J., Konečný, V. et al. Motor vehicle tax in the Slovak Republic. Research study. University of Žilina, Žilina, 2010.

[2] Gnap. J., Konečný, V. et al. Motor vehicle tax in the Slovak Republic. Research study. University of Žilina, Žilina, 2012.

[3] Konečný, V., Gnap, J. European carriers balance their costs. Transport manager, 2017, Vol. 28, No. 4 pp. 128-137. ISSN 2300-164X.

[4] Barker, T., Kohler, J. Charging for road freight in the EU - Economic implications of a weigh-in-motion tax. Journal of Transport Economics and Policy, 2000, Vol. 34, pp. 311-331, Part: 3.

[5] Leontyeva, Y., Mayburov, I. Assessment of tax burden on the ownership and use of road freight transport in Russia. In: Innovation, entrepreneurship and digital ecosystems. 9th Annual Conference of the EuroMed-Academy-ofBusiness, 2016
[6] Vierth, I., Schleussner, H., Mandell, S. Road freight transport policies and their impact: A comparative study of Germany and Sweden. International Journal of Transport Economics, 2017, Vol. 44, Issue 2, pp. 213-234. DOI: 10.19272/201706702003.

[7] Vega, A., Evers, N. Implications of the UK HGV road user charge for Irish export freight transport stakeholders - A qualitative study. Case Studies on Transport Policy, 2016, Vol. 4, Issue 3, pp. 208-217. https://doi.org/10.1016/j. cstp.2016.04.001

[8] Suarez-Aleman, A. Short sea shipping in today's Europe: A critical review of maritime transport policy. Maritime Economics \& Logistics, 2016, Vol. 18, Issue 3, pp. 331-351. https://doi.org/10.1057/mel.2015.10

[9] Bartuska, L., Biba, V., Kampf, R. Modeling of Daily Traffic Volumes on Urban Roads. 3rd International Conference on Traffic and Transport Engineering (ICTTE2016). Belgrade, Serbia, Nov. 24-25, 2016, pp. 900-904.

[10] Kampf, R., Lizbetinova, L., Tislerova, K. Management of Customer Service in Terms of Logistics Information Systems. Open Engineering, 2017, Vol. 7, Issue 1, pp. 26-30. https://doi.org/10.1515/eng-2017-0006

[11] Greven, M. Tax Guide 2016. ACEA - European Automobile Manufacturer's Association, 2016. Available via: http://www.acea.be/collection/taxation publications.

[12] Konečný, V., Gnap, J., Šimková, I. Impact of fiscal decentralization on motor vehicle taxation in the Slovak republic. Transport and telecommunication, 2016, Vol. 17, No. 1, pp. 28-39. ISSN 1407-6160.

[13] Barbour, K.A. The Effects of Motor Vehicle Wealth Taxes on Households Vehicle Purchase Decisions. Journal of Economics and Economic Education Research, 2009, Vol. 10, No. 3. ISSN 1533-3604.

[14] Barrios S., Strobl E. The Dynamics of regional inequalities. Economic Papers No.229 Brusel (European Commission. Directorate General for Economic and Financial Affairs), 2005.

[15] Boldrin M., Canova, F. Inequalities and convergence in Europe's regions. Reconsidering European Regional Policies. Economic Policy, 2001, Vol. 32, pp. 205-253. https://doi.org/10.1111/1468-0327.00074

[16] Poliak, M. Impact of road network charging system on pricing for general cargo transportation. Promet-Traffic \& transportation, 2012, Vol. 24, Issue 1, pp. 25-33. ISSN 1848-4069.

[17] Buková, B., Brumerčíková, E., Kondek, P. Value added tax in forwarding. Logi - Scientific Journal on Transport and Logistics, 2015, Vol. 6, No. 2, pp. 6-12. ISSN 1804-3216.

[18] Varjan, P. Comparison of revenue and expenditures of road and railway transport in the Slovakia. Logi - Scientific Journal on Transport and Logistics, 2014, Vol. 5, No. 2, pp. 108-115. ISSN 1804-3216.

[19] Directive 1999/62/EC on the charging of heavy goods vehicles for the use of certain infrastructures.

[20] Directive 2006/38/EC amending Directive 1999/62/EC on the charging of heavy goods vehicles for the use of certain infrastructures.

[21] Report from the Commission to the European Parliament and the Council on the State of the Union Road Transport Market, EUROPEAN COMMISSION $\operatorname{COM(2014)} 222$ final, Brussels, 2014. 